\section{Clinical evaluation of 107 anterior teeth restored with direct nanofilled resin composite: up to 32 months}

\section{Nanofil rezin kompozitlerle restore edilmiş 107 anterior dişin klinik olarak değerlendirilmesi: 32 aylık takip}

\begin{abstract}
Assist. Prof. Tuğba Toz Akalın Istanbul Medipol University, Faculty of Dentistry, Department of Restorative Dentistry, Istanbul
\end{abstract}

Assist. Prof. Mahmut Kuşdemir Istanbul Medipol University, Faculty of Dentistry, Department of Restorative Dentistry, Istanbul

Assist. Prof. Harika Gözükara Bağ Inonü University, School of Medicine, Department of Biostatistics, Malatya

Prof. Mutlu Özcan

Dental Materials Unit, Center for Dental and Oral Medicine, Clinic for Fixed and Removable Prosthodontics and Dental Materials Science, University of Zurich, Switzerland

Received: 18 April 2016

Accepted: 23 June 2016

DOI: 10.5505/yeditepe.2016.87587

Corresponding author:

Assist. Prof. Dr. Tuğba Toz Akalın

Department of Restorative Dentistry, Istanbul Medipol University

Atatürk Bulvarı 34083, Fatih, Unkapanı, Istanbul, Turkey

Tel: +905433242554

Fax: +902125210426

Email: ttoz@medipol.edu.tr

\section{SUMMARY}

Aim: This study evaluated the clinical performance of a nanofill resin composite in Class III and IV cavities.

Materials and Methods: One hundred and seven Class III and Class IV restorations were performed with a nanofill resin composite. Restorations were evaluated using the modified USPHS/FDI criteria. The changes were analyzed using McNemar and Marginal Homogeneity and Kaplan-Meier tests.

Results: Fourteen absolute failures were encountered resulting in a survival rate of $\mathbf{8 6 . 8 \%}$ (Kaplan-Meier). Nanofill resin composite showed acceptable clinical performance up to 32 months of service.

Conclusion: However color stability and retention decreased at the end of two year fol-low up instead of fractures.

Key words: Adhesion, class III cavities, nanofilled composite resin

\section{ÖZET}

Amaç: Bu çalışmanın amacı, nanofil bir rezin kompozitin klinik performansının sınıf 3 ve sınıf 4 kavitelere yapılan restorasyonlar ile değerlendirilmesidir.

Gereç ve Yöntem: 107 adet sınıf 3 ve sınıf 4 restorasyon nanofil rezin kompozit ile re-store edildi ve daha sonra modifiye USPHS/FDI kriterleri ile değerlendirildi. Sonuçlar McNemar ve Marjinal Homojenite ve Kaplan-Meier testleri ile analiz edildi.

Bulgular: 14 adet restorasyonda başarısızlık tespitiyle birlikte $\% 86,8$ lik bir restorasyon başarı oranı yakalandı. Nanofil rezin kompozitin 32 aylık periyotta kabul edilebilir bir klin-ik başarı gösterdiği tespit edildi.

Sonuç: 2 yıllık takip sonunda renk stabilitesi ve retansiyonun azaldığı belirlendi.

Anahtar kelimeler: Adezyon, class III kaviteler, nanofil kompozit rezin

\section{INTRODUCTION}

One of the most significant contributions to dental technology has been the introduction of adhesive dentistry. Regarding the adhesive restorative materials from the time they were introduced to dental clinicians, a significant evolution was observed ${ }^{1}$ and with this evolution these materials have gained the advantage of preserving sound tooth tissue and providing acceptable esthetic. ${ }^{2}$ Minimal invasive treatments avoid reaching an early end of a "tooth's lifecycle" and therefore they are more preferable. During the replacement of decayed or missing tooth tissue, dentists achieve excellent esthetic results with direct res-in composites with a variety of colors and effects. ${ }^{3}$

Microfilled resin composites were developed to eliminate the rough surface characteristic of macrofilled materials. These restoratives have worse mechanical properties instead of improved handling and polishing properties. In an effort to maintain the advantages of both conventional and micro- 
filled resins, hybrid resin composites were introduced to cli-nicians. These materials have a smoother surface characteristic due to smaller particular ingredients. ${ }^{4}$ Further efforts in filler technology resulted in microhybrid composites named as universal composites which are used for both anterior and posterior areas. ${ }^{5}$

Apart from conventional resin composites, nanofill and/or nanohybrid adhesive restora-tive materials represent the state of the art in terms of filler ingredient and have a similar or slightly better performance. ${ }^{6}$ In addition to the advantages of nano fill and/or nanohy-brid resin composites such as strength, low wear, and polishability these materials general-ly has different shades, allowing the natural dental tissue reproduction in an efficient way, with the stratification technique. ${ }^{1}$ Nanofill resin composites are composed of both nanomer and nanoclusters, whereas nanohybrid is a hybrid resin composite with nanofiller in a prepolymerized filler (PPF) form.7 Filtek Ultimate Universal Restorative (3M ESPE, St.Paul, MN, USA) is a nanofill resin composite largely used in the daily practice. The material contains Bis-GMA, urethane dimethacrylate (UDMA), triethylene glycol di-methacrylate (TEGDMA), and Bis-EMA resins. The inorganic filler loading is about $78.5 \%$ by weight ( $63.3 \%$ by volume). The including fillers are a combination of silica, zirco-nia and aggregated zirconia/silica cluster fillers. The dentin, enamel, and body shades that have been used in the study have an average cluster particle size of 0,6-10u. ${ }^{8}$

The knowledge that is necessary for the decision of restorative material by clinician is reserved from the results of in vitro and in vivo literature. Even though in vitro evaluations have the advantage of high reproducibility, in vivo literature is necessary for the final evaluation of a restorative material due to factors which can not be simulated in vitro conditions. ${ }^{9}$ In daily practice, an evidence-based approach and clinical observations are becoming more expected of dentists. Clinical evaluations of direct adhesive restorations showed good wear resistance and adaptation to tooth tissues; however they also have a high replacement rate due to seconder caries and low color stability. ${ }^{10}$ Although there were various clinical evaluations of direct posterior composite restorations, ${ }^{11-13}$ reliable data about the clinical performance of direct anterior restorations is rare. Thus the aim of this study was to evaluate the clinical performance of a nano hybrid resin composite (Fil-tek Ultimate) in Class III and IV cavities.

\section{MATERIALS AND METHODS}

The brands, manufacturers and chemical composition of the materials used in this study are listed in Table 1.

\section{Study Design}

Patients who have at least two anterior teeth with decay and met the inclusion criteria were included in this study which was performed between January-2013 and October-2014. Participants recruited for this study were referred from the surrounding local gen-eral practices. Before entering the trial, all patients were provided with informed consent form approved by the ethical committee of the university institutional review board (1084009854). Information was given to each patient regarding the alternative treatment options.

Table 1: The brand, type, manufacturer, and chemical composition of the main materials used in this study

\begin{tabular}{|l|l|l|l|}
\hline Brand Name & Type & Manufacturer & ChemiCal Composition \\
\hline Dycal & $\begin{array}{l}\text { Clacium hydroxi- } \\
\text { de }\end{array}$ & $\begin{array}{l}\text { Dentsply Caulk, Kon- } \\
\text { stanz, Germany }\end{array}$ & $\begin{array}{l}\text { Base paste: Disalicylate ester of } \\
1,3, \text { butylene glycol; calcium } \\
\text { phosphate; calcium tungstate; } \\
\text { zinc oxide; iron oxide Catalyst } \\
\text { paste: calcium hydroxide; ethyl } \\
\text { toluenesulfonamide; zinc } \\
\text { sterate; titanium dioxide; zinc } \\
\text { oxide; iron oxide }\end{array}$ \\
\hline Filtek Ultimate & $\begin{array}{l}\text { Nanofilled resin } \\
\text { composite, light- } \\
\text { cured, universal }\end{array}$ & $\begin{array}{l}\text { 3M ESPE, St. Paul, MN, } \\
\text { USA }\end{array}$ & $\begin{array}{l}\text { Filler type: Zirconia/silica, } \\
\text { zirconia, silica } \\
\text { Resin matrix: BISGMA, BI- } \\
\text { SEMA, UDMA, TEGDMA, } \\
\text { PEGDMA }\end{array}$ \\
\cline { 2 - 3 } Bond 2 & $\begin{array}{l}\text { Two step etch and } \\
\text { rinse adhesive }\end{array}$ & USA ESPE, St. Paul, MN, & $\begin{array}{l}\text { 2-HEMA, Bis-GMA, Di- } \\
\text { methacrylates,Amins, Methac- } \\
\text { rylaTE Functional co- } \\
\text { polymer of polyaacrylic and } \\
\text { polyitaconic acid, ethanol, wa- } \\
\text { ter, photoinitiator }\end{array}$ \\
\hline
\end{tabular}

\section{Patient inclusion/exclusion criteria}

The inclusion and exclusion criteria were as follows: Inclusion Criteria:

1. Good general health.

2. Having at least two Class III and/or Class IV carious lesions or existing defective res-torations, including proximal surfaces in permanent maxillary anterior teeth, which were asymptomatic.

Exclusion Criteria:

1. Absence of adjacent and antagonist teeth.

2. Severe periodontal diseases and poor oral hygiene.

3. Symptoms of pulpitis, such as spontaneous pain or sensitivity to pressure.

\section{Tooth preparation}

One operator with experience in adhesive dentistry, more than 12 years since graduation, placed a total of 107 restorations in 34 patients (18 female, 16 male; mean age $35.4 \pm 13.5$ years old, range: $18-57$ years old) with the help of a dental assistant. The teeth were cleaned and the color was determined by the a custom composite sample or Vita Shade Guide (VITA Zahnfabrik, Germany). After the shade selection preparations were cut un-der local anesthesia if it was necessary. The cavity design (restricted to the elimination of carious tissue or defective restorations) was prepared using diamond and stainless steel burs (Diatech, Heerbrugg, Switzerland) and all buccal enamel cavosurface margins were beveled. All preparations were performed as adhesive-only cavities. The pulp tissue was 
protected with calcium hydroxide (Dycal, Dentsply Detrey; Konstanz, Germany) in deeper cavities when when the remaining dentin on the cavity floor was close to the pulp. Glass ionomer liner (Glass-Liner, Willmann\&Pein Gmbh, Hamburg, Germany) was ap-plied to cover the calcium hydroxide; therefore, most of the dentin surface was left ex-posed for adhesion.

\section{Restorative procedure}

The teeth were restored esthetically with a nano hybrid resin composite using etch-and rinse technique. Isolation was achieved with cotton rolls and suction instead of rubber dam and retraction cords (Ultrapak, Ultradent, USA) were used to minimize crevicular fluid flow. To ensure optimal adhesive bonding, a two-step etch and rinse adhesive sys-tem (Adper Single Bond 2, 3M ESPE, St.Paul, $M N, U S A)$, which is included the etching procedure with phosphoric acid (3M ESPE, St.Paul, MN, USA) was used. Enamel surfaces were conditioned for 30 seconds while dentin surfaces were conditioned for 15 seconds with phosphoric etching gel. After etching, the cavities were water rinsed thoroughly for $30 \mathrm{~s}$ with water, and afterwards clorhexidine antibacterial solution (Con-sepsis, Ultradent South Jordan, UT, USA) to remove the acidic agent and the teeth were dried by gently air blowing. Adhesive was applied with a disposable brush and tooth sur-faces were scrubbed with brushing motion for 20 s. This application was repeated second-ly with a new drop of adhesive with $20 \mathrm{~s}$ waiting period in between the coats. The surfac-es were dried with gentle air blowing and then medium at least $5 \mathrm{~s}$ and light cured for 20s (Guilin Woodpecker Medical Instrument Co., Ltd, China) according to the manufactur-er's instructions.

The nanofill resin composite (Filtek Ultimate) was used for the composite build-ups due to its good handling property and shade matching. The resin composite was placed and polymerized using incremental layering technique as dentin, body and enamel composite to simulate natural tooth color and translucency. Restorations were light-cured for $40 \mathrm{sec}$-onds each from facial and lingual directions. Particular attention was given to the con-touring of the apical finish line of the restorations. After polymerization checking the oc-clusion, finishing and polishing of the restorations took place with finishing burs, polish-ing discs Opti Disc (Kerr Corporation, CA, USA) and rubbers HiLuster PLUS Polishing System (Kerr Corporation, CA, USA).

\section{Evaluation}

Two calibrated observers different from the operator evaluated the restorations at base-line, at 6 months, and at final recall. For maximum validity, both examiners were cali-brated by using the recommended web- based train- ing and calibration tool. ${ }^{14}$ Restorations were evaluated, according to the modified United States Public Health Service (USPHS) criteria or FDI criteria. ${ }^{15,16}$ According to these criteria, clinically excellent restorations were scored as 1 , clinically good restorations as 2 , clinically sufficient restorations as 3 , and clinically unsatisfactory and clinically poor restorations as 4 and 5, respectively. The restorations were inspected visually with a dental mirror and probe. Caries, chipping, debonding, fractures, and severe discoloration were considered as absolute failures. Pa-tients were instructed to call the researchers in the event of any kind of failure. In case of an unfavorable event, such as chipping of direct adhesive restorative materials, the date of the event was recorded. If it was impossible to identify the exact date of a defect, or the defect was detected only during the recall observation, the date of the unfavorable event was accepted as the date when the dentist observed the damage. All data were recorded by typing directly into an anonymous database.

When a complete restoration was lost or was impossible to repair, or the restarted tooth required root canal treatment, the restoration was deemed a failure. When less damaging events occurred, such as minor composite fractures, chipping fractures, marginal gaps, caries, or color or surface deterioration, the restorations were repaired, polished, and the type of unfavorable event was documented in the patients' record. These cases were de-fined as survival cases. Restorations having no failure or unfavorable event were classi-fied as a success.

\section{Statistical analysis}

Survival analyses were performed with statistical software program (SPSS 21,0; SPSS Inc, Chicago, IL, USA) using Kaplan-Meier test to obtain the survival rates in relation to observation time. $P$ values less than 0,05 were considered to be statistically significant in all tests. To compare changes in the quality parameters between observations, the marginal homogeneity test was used.

\section{Results}

Results of the clinical evaluations of the 107 restorations at baseline, 6 months, 1 year and final recalls are shown in Table 2. In total, no drop-out was experienced yielding to the evaluation of 107 direct anterior restorations. The mean observation time was $22.4 \pm 7$ months with a minimum observation period of 9.63 months and maximum 32.10 months. Of these 107 direct restorations 3 restorations were located in the mandible and 104 in the maxilla and 48 restorations were Class III and 79 restorations were Class IV.

Most of the restorations were scored as clinically excellent at baseline and six-month re-calls. Secondary caries and endodontic complications were not detected in 
any of the teeth. At the 1-year recalls, 106 restorations (99.06\%) restorations were classified as suc-cessful.

Table 2: Summaries of USPHS Evaluations at baseline, six months and final recalls.

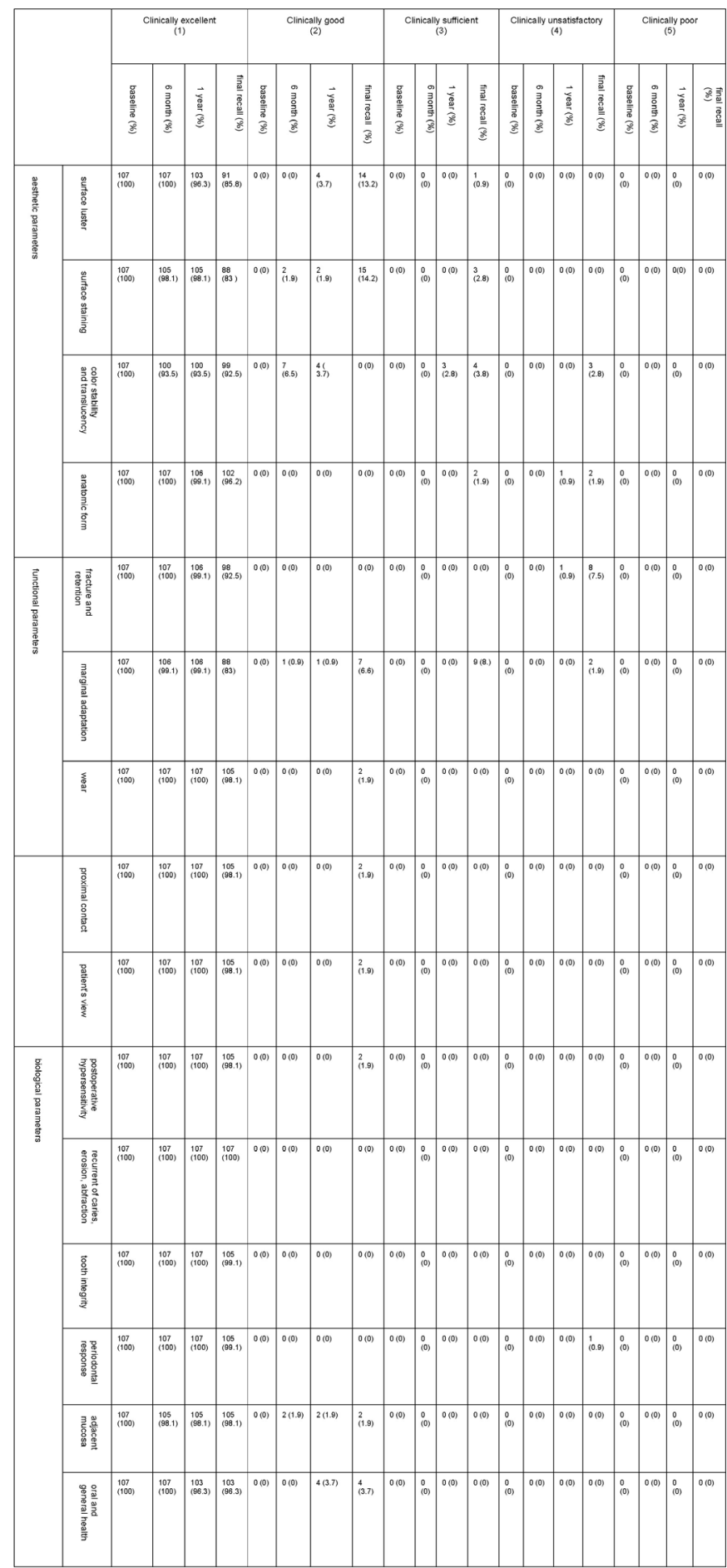

One restoration $(0.9 \%)$ was retreated due to the chipping at the margins and rec-orded as failure. One $(0.9 \%)$ restorations showed unfavorable event (chip fracture not affecting the marginal integrity) was repolished and accepted as survival case. During the follow-up periods, 92 $(86.8 \%)$ restorations were accepted as clinically acceptable; ${ }^{18}(16.9 \%)$ were repaired and they were accepted as survival cases. Fourteen $(13.2 \%)$ resto-rations were classified as failures, due to color mismatches, chipping and fractures and were retreated and recorded as failure (Table 3). The data for survival without failure and unfa- vorable events are shown in a Kaplan-Meier plot in Figure 1 and 2, with a sur-vival rate, after 1 year of 99.1 and at up to 32 months, of 86.8 . The mean survival time ( \pm standard error) was $30.1 \pm 0.6$ months [95\%C.I. $=(28.97-31.23)]$.

Table 3: The distribution of failures according to the evaluated USPHS/FDI criteria.

\begin{tabular}{|c|c|c|c|c|c|c|}
\hline & & \multicolumn{5}{|c|}{ USPHS/FDI criteria } \\
\hline & & $\begin{array}{c}\text { color stability } \\
\text { and translu- } \\
\text { cency }\end{array}$ & $\begin{array}{c}\text { anatomic } \\
\text { form }\end{array}$ & $\begin{array}{l}\text { fracture and } \\
\text { retention }\end{array}$ & $\begin{array}{l}\text { marginal } \\
\text { adapta- } \\
\text { tion }\end{array}$ & $\begin{array}{l}\text { periodon } \\
\quad \text { tal } \\
\text { response }\end{array}$ \\
\hline $\begin{array}{c}1 \text { year recall ( } 1 \text { failed resto- } \\
\text { rations) }\end{array}$ & 1 & - & - & $\begin{array}{l}\text { Clinically } \\
\text { unsatisfac- } \\
\text { tory }\end{array}$ & - & - \\
\hline \multirow[t]{14}{*}{$\begin{array}{c}\text { Final recall } \\
\text { (14 failed restorations) }\end{array}$} & 1 & - & $\begin{array}{c}\text { Clinically } \\
\text { unsatis- } \\
\text { factory }\end{array}$ & $\begin{array}{l}\text { Clinically } \\
\text { unsatisfac- } \\
\text { tory }\end{array}$ & - & - \\
\hline & 2 & - & $\begin{array}{c}\text { Clinically } \\
\text { unsatis- } \\
\text { factory }\end{array}$ & $\begin{array}{l}\text { Clinically } \\
\text { unsatisfac- } \\
\text { tory }\end{array}$ & - & - \\
\hline & 3 & - & - & - & - & $\begin{array}{l}\text { Clinical- } \\
\text { ly unsat- } \\
\text { isfactory }\end{array}$ \\
\hline & 4 & $\begin{array}{c}\text { Clinically } \\
\text { unsatisfactory }\end{array}$ & - & - & - & - \\
\hline & 5 & $\begin{array}{c}\text { Clinically } \\
\text { unsatisfactory }\end{array}$ & - & - & - & - \\
\hline & 6 & $\begin{array}{c}\text { Clinically } \\
\text { unsatisfactory }\end{array}$ & - & - & - & - \\
\hline & 7 & - & - & $\begin{array}{l}\text { Clinically } \\
\text { unsatisfac- } \\
\text { tory }\end{array}$ & - & - \\
\hline & 8 & - & - & $\begin{array}{l}\text { Clinically } \\
\text { unsatisfac- } \\
\text { tory }\end{array}$ & - & - \\
\hline & 9 & - & - & $\begin{array}{l}\text { Clinically } \\
\text { unsatisfac- } \\
\text { tory }\end{array}$ & - & - \\
\hline & 10 & - & - & $\begin{array}{l}\text { Clinically } \\
\text { unsatisfac- } \\
\text { tory }\end{array}$ & - & - \\
\hline & 11 & - & - & - & $\begin{array}{l}\text { Clinically } \\
\text { unsatis- } \\
\text { factory }\end{array}$ & - \\
\hline & 12 & - & - & - & $\begin{array}{c}\text { Clinically } \\
\text { unsatis- } \\
\text { factory }\end{array}$ & - \\
\hline & 13 & - & - & $\begin{array}{l}\text { Clinically } \\
\text { unsatisfac- } \\
\text { tory }\end{array}$ & - & - \\
\hline & 14 & - & - & $\begin{array}{l}\text { Clinically } \\
\text { unsatisfac- } \\
\text { tory }\end{array}$ & - & - \\
\hline
\end{tabular}

The clinical evaluations of the 107 restorations at baseline, 6 months, and final recalls are shown in Table 2. The statistically significant differences were observed for the criteria of color stability at six month $(p=0,016)$. Seven restorations showed minor deviations in translucency and scored as clinically good. At one year recall except the failed restoration three restorations showed deterioration in color; two of them were highly translucent while the other was more darker $(p=0.012)$. At final recalls the statistically significant differences were observed for the criteria of surface luster $(p<0,001)$, surface staining $(p<0.001)$, color stability and translucency $(p=0,010)$, fracture and retention ( $p=0.008)$ and marginal adaptation $(p<0,001)$. For the criteria of surface luster 14 restorations were observed as slightly dull. However they were not noticeable from speaking distance. Mi-nor marginal and surface staining were observed at 15 restorations and 
they were re-moved by repolishing. These restorations were accepted as survival. Three restorations were too darker that they were corrected by repair and accepted as failure. Eight restora-tions were scored as clinically unacceptable for the criteria of "fracture of material and retention"; six of them showed chipping that damages marginal quality while bulk frac-tures were observed at two restorations. Larger irregularities with the necessity of repair were observed at the other two restorations. These restorations were also accepted as fail-ure.

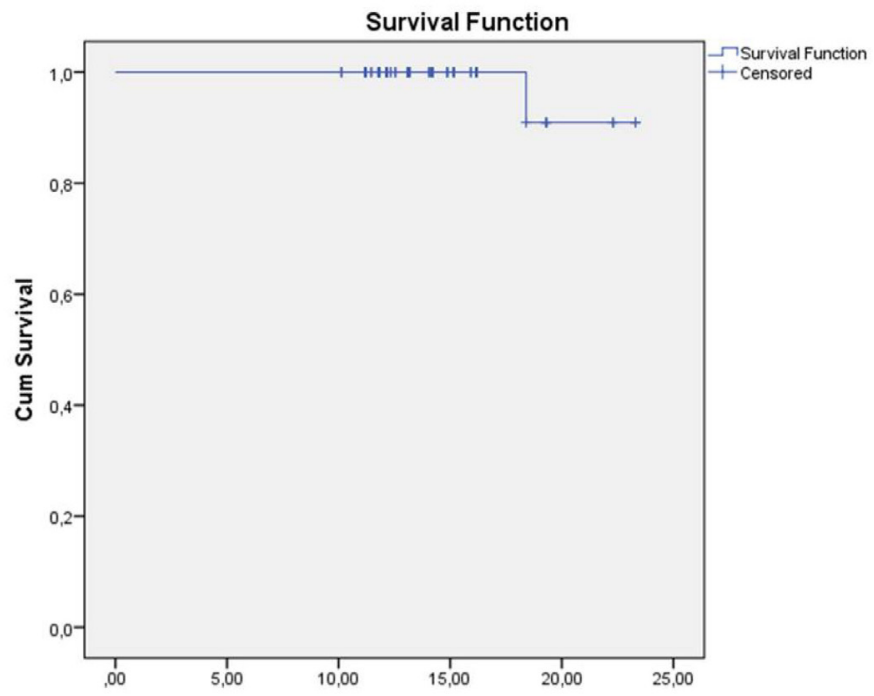

Figure 1: Kaplan-Meier plot with the survival rate showed the survival without failure and unfavorable event after 1 year.

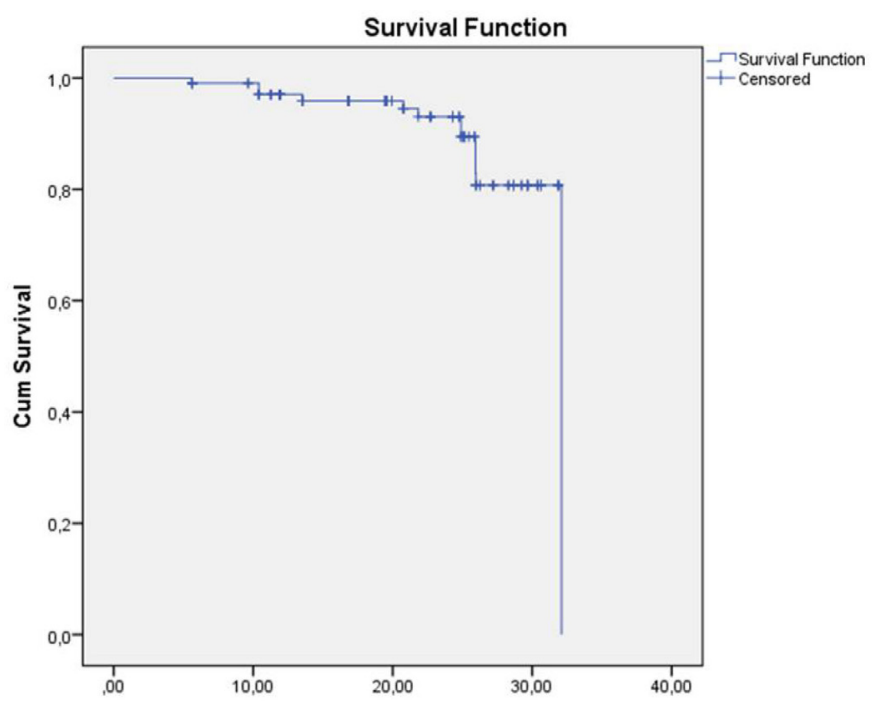

Figure 2: Kaplan-Meier plot with the survival rate showed the survival without failure and unfavorable event after up to 32 months.

\section{DISCUSSION}

Resin composites have gained popularity as restorative materials due to their esthetic and adhesive properties since their introduction to dentistry ${ }^{5}$ and currently, accepted as the first choice to restore both anterior and posterior teeth. ${ }^{17}$ There are several journals observ-ing the clinical behavior of posterior resin composite restorations in the literature. These journals usually revealed that posterior resin restorations might present low annual failure rates and long-lasting survival. ${ }^{12,18}$ with failure reasons such as secondary caries and frac-ture. ${ }^{18,19}$ Despite the extended usage of resin composites in anterior restorations, there is a lack of evidence from clinical observations regarding the performance of anterior restora-tions especially in long term.

In the present investigation, a two-step etch and rinse adhesive system was used to ensure optimal adhesive bonding after the etching of enamel surfaces for $30 \mathrm{sec}-$ onds with phos-phoric etching gel. The marginal quality of the restorations were observed generally suc-cessful at final recalls due to the etch and rinse adhesive procedure applied in the study. Some studies reported that etch\&rinse adhesives or additional etching exhibited higher percentages of gap free margins in enamel after thermo-mechanical loading when com-pared to two-step self-etch adhesives. ${ }^{20}$ Ermis et al. ${ }^{21}$ also mentioned in their clinical study that additional etching of the enamel margins improved the marginal quality of res-torations bonded with this adhesive system.

The most obvious reason for failures in anterior restorations are directly or indirectly relat-ed to the esthetic appearance of a tooth or restoration, while secondary caries is seldom the reason for replacement and endodontic complications are limited. Anterior restora-tions generally behave differently from posterior restorations. The restoration loss of ante-rior region is more present than in posterior teeth and esthetic appearance plays an obvious role in the desire of the patient to have a restoration replaced..$^{22}$ In our study the patients are satisfied with the esthetically appearance of their final restorations. Failures at final recalls were generally related with the loss of retention or fracture or bad marginal quality. Only 3 restorations were retreated due to the criteria of color stability and translucency. The perception of aesthetics itself may vary among individuals according to their age, educational level, and environment to which they are exposed. The higher patient satis-faction scores in our clinical observations can be related with these aspects.

The available literature is still insufficient to determine the longevity of direct anterior adhesive restorations. Many variables, like the size, location and type of restoration ${ }^{23}$ and the patient's dentition ${ }^{24}$ affect the longevity of composite restorations. In anterior teeth, Class IV restorations involving the incisal edge are subjected to high masticatory loads, with fracture as a possible clinical outcome over time. ${ }^{17}$ The lack of mechanical retention in most Class IV restorations may lead to a greater challenge to the tooth-restoration bonded interface. ${ }^{25}$ van Dijken and Pallesen ${ }^{26}$ found a higher prevalence of failure in Class IV restorations performed with different materials in bruxers, indicating that over-loading in individuals with occlusal disturbances may increase the mechanical stresses in 
the restorations, making them more prone to fracture. Lucarotti et al. ${ }^{27}$ reported that in-volvement of the incisal angle in incisors and canine teeth resulted in an associated reduc-tion in median survival time. In our clinical observation we performed 48 Class III and 79 Class IV restorations. This repair protocol can be accepted as sufficiently flexible to allow for improving the shape, surface luster, or marginal staining even after long clinical periods.

At final recalls 8 restorations were retreated due to the chipping, fracture and loss of res-torations and all of them were Class IV restorations. These scores can be related with the high masticatory loads that the restorations were exposed. It seems that failure behavior in anterior restorations is different from posterior teeth, with less secondary caries pre-sent. ${ }^{22}$ No secondary caries was observed for any of the restorations.

Spinas $^{28}$ reported that, despite repairs of restorations, interventions like repolishing were alternative procedures that could be repeated several times as necessary. The survival rate in our study provides evidence that minimal repair procedures, such as repolishing, can be accepted as an important factor in prolonging the clinical success of direct adhesive resto-rations. Daily clinical experiences show that minor unfavorable events are generally easy to repair. ${ }^{16}$ Reuses et al. ${ }^{29}$ observed microfilled and hybrid anterior restorations and ob-served higher marginal discoloration for the microfilled resin composite. They accepted that hybrid resin composites performed well as an anterior restorative material. Microfill restorations were polishable but were weak because of their relatively low filler content. Thus, since then, the particle size of the conventional composites has been reduced through further grinding to produce more advanced restorative materials. Microhybrid resin composites were generally accepted as universal composites, with these materials used for most anterior and posterior regions. When combined, these materials improved strength and polishability characteristics. ${ }^{5}$ Narhi et al..$^{30}$ evaluated the clinical behavior of microhybrid anterior restorations after 1 year and found the performance of the restora-tions to be clinically acceptable, similar with the clinical observations of Peumans et al. ${ }^{31,32}$

One of the biggest innovations could be the development of nanofill and nanohybrid res-in composites. Nanohybrid properties, such as flexure strength and modulus, tend to be similar to those of microhybrids; however, they can be considered, as a group, to be in the lower range of the microhybrids, with both being superior to previous microfills. ${ }^{5}$ Similar to the preceding resin composites, nanofill anterior restorations showed acceptable clinical behavior in our in vivo evaluations after up to 32 months.

\section{CONCLUSIONS}

Within the limitations of the current design and recall period, the following could be con-cluded:

1. Direct Class III and IV restorations made of nanofilled resin composite presented $86.8 \%$ survival.

2. Repair and maintance protocols were practiced to prolong the restoration lifetime al-ready after 6 months to improve marginal adaptation, surface staining and lusture and morphology which deteriorated in some cases up to clinical service time of 32 months.

\section{Acknowledgement}

The authors acknowledge dental assistants Miss B. Yildiz from Istanbul Medipol University, School of Dentistry, Department of Restorative Dentistry Clinics, for organizing the recalls of the patients.

\section{Conflict of interest}

The authors did not have any commercial interest in any of the materials used in this study.

\section{REFERENCES}

1. de Carvalho LD, Machado RG, Lopes GC, de Andrada MC. Nanofilled composite restorations with different adhesives strategies: clinical cases. Case Rep Dent 2012: 969627.

2. Loguercio $A D$, Lorini $E$, Weiss RV, Tori AP, Picinatto $C C$, Ribeiro NR, Reis A A 12-month clinical evaluation of composite resins in class III restorations. J Adhes Dent 2007; 9: 57-64.

3. Pontons-Melo JC, Furuse AY, Mondelli J A direct composite resin stratification tech-nique for restoration of the smile. Quintessence Int 2011; 42: 205-211.

4. van der Veen HJ, Pilon HF, Henry PP Clinical performance of one microfilled and two hybrid anterior composite resins. Quintessence Int 1989; 20: 547-550.

5. Ferracane JL Resin composite--state of the art. Dental Mater 2011; 27: 29-38.

6. Can Say E, Yurdaguven H, Yaman BC, Ozer F. Surface roughness and morphology of resin composites polished with two-step polishing systems. Dent Materials J 2014; 33: 332-342.

7. Senawongse $P$, Pongprueksa P.J Surface roughness of nanofill and nanohybrid resin composites after polishing and brushing. J Esthet Restor Dent 2007; 19: 265-273.

8. Prodan DA, Gasparik C, Mada DC, Miclăuş V, Băciuţ M, Dudea D Influence of opacity on the color stability of a nanocomposite Clin Oral Invest 2015; 19: 867-875.

9. Geitel B, Kwiatkowski R, Zimmer S, Barthel CR, Roulet JF, Jahn KR Clinically con-trolled study on the quality of class III, IV and V composite restorations after two years. J Adhes Dent 2004; 6: 247-253.

10. van Dijken JW Longevity of new hybrid restorative 
materials in class III cavities. Eur J Oral Sci 1999; 107: 215-219.

11. Manhart J, Chen HY, Hickel R Clinical evaluation of the posterior composite Quixfil in class I and II cavities: 4-year follow-up of a randomized controlled trial. J Adhes Dent 2010; 12: 237-243.

12. Da Rosa Rodolpho PA, Donassollo TA, Cenci MS, Loguercio AD, Moraes RR, Bronkhorst EM, Opdam NJ, Demarco FF 22-Year clinical evaluation of the performance of two posterior composites with different filler characteristics. Dent Mater 2011; 27:955-963.

13. Lempel E, Toth A, Fabian T, Krajczar K, Szalma J Retrospective evaluation of poste-rior direct composite restorations: 10-Year findings. Dent Mater 2015; 31: 115-122.

14. Hickel R, Peschke A, Tyas M, Mjör I, Bayne S, Peters M, Hiller KA, Randall R, Vanherle G, Heintze SD FDI World Dental Federation - clinical criteria for the evalua-tion of direct and indirect restorations. Update and clinical examples. J Adhes Dent 2010; 12: 259-272.

15. Hickel R, Roulet JF, Bayne S, Heintze SD, Mjor IA, Peters $M$, Rousson V, Randall R, Schmalz G, Tyas M, Vanherle G Recommendations for conducting controlled clinical studies of dental restorative materials. Int Dent J 2007; 57: 300-302.

16. Frese $C$, Schiller $P$, Staehle $H J$, Wolff D Recontouring teeth and closing diastemas with direct composite buildups: a 5-year follow-up. J Dent 2013; 41:979-985.

17. Baldissera RA, Correa MB, Schuch HS, Collares K, Nascimento GG, Jardim PS, Moraes RR, Opdam NJ, Demarco FF Are there universal restorative composites for ante-rior and posterior teeth? J Dent 2013; 41:1027-1035.

18. Opdam NJ, van de Sande FH, Bronkhorst E, Cenci MS, Bottenberg P, Pallesen $U$, Gaengler P, Lindberg A, Huysmans MC, van Dijken JW. Longevity of posterior composite restorations: a systematic review and meta-analysis. J Dent Res 2014; 93: 943-949.

19. Demarco FF, Correa MB, Cenci MS, Moraes RR, Opdam NJ Longevity of posterior composite restorations: not only a matter of materials. Dent Mater 2012; 28: 87101.

20. Frankenberger $R$, Tay FR Self-etch vs etch-and-rinse adhesives: effect of thermo-mechanical fatigue loading on marginal quality of bonded resin composite restorations. Dental Mater 2005; 21: 397-412.

21. Ermis RB, Temel UB, Cellik EU, Kam O Clinical performance of a two-step self-etch adhesive with additional enamel etching in Class III cavities. Oper Dent 2010; 35: 147-155.

22. Demarco FF, Collares K, Coelho-de-Souza FH, Correa MB, Cenci MS, Moraes RR, Opdam NJ. Anterior composite restorations: A systematic review on long-term survival and reasons for failure. Dent Mater 2015; 31: 1214-1224.

23. Qvist V, Strom C 11-year assessment of Class-III resin restorations completed with two restorative procedures. Acta Odontol Scand 1993; 51: 253-262.

24. Hunter B Survival of dental restorations in young patients. Community Dent Oral Epidemiol 1985; 13: 285287.

25. Heintze SD, Rousson V, Hickel R Clinical effectiveness of direct anterior restora-tions-a meta-analysis. Dent Mater 2015; 31: 481-495.

26. van Dijken JW, Pallesen U Fracture frequency and longevity of fractured resin com-posite, polyacid-modified resin composite, and resin-modified glass ionomer cement class IV restorations: an up to 14 years of follow-up. Clin Oral Invest 2010; 14: 217-222.

27. Lucarotti PS, Holder RL, Burke FJ Outcome of direct restorations placed within the general dental services in England and Wales (Part 1): variation by type of restoration and re-intervention. J Dent 2005; 33: 805-815.

28. Spinas E Longevity of composite restorations of traumatically injured teeth. Am J Dent 2004; 17: 407-411.

29. Reusens, B, D'Hoore W \& Vreven J In vivo comparison of a microfilled and a hybrid minifilled composite resin in Class III restorations: 2-year follow-up Clin Oral Invest 1999; 3: 62-69.

30. Närhi TO, Tanner J, Ostela I, Narva K, Nohrström T, Tirri T \& Vallittu PK Anterior Z250 resin composite restorations: one-year evaluation of clinical performance. Clin Oral Invest 2003; 7: 241-243.

31. Peumans $M$, Van Meerbeek $B$, Lambrechts $P$ \& Vanherle $G$ The 5-year clinical per-formance of direct composite additions to correct tooth form and position. I. Esthetic qualities. Clin Oral Invest 1997; 1: 12-18.

32. Peumans $M$, Van Meerbeek $B$, Lambrechts $P$ \& Vanherle $G$ The 5-year clinical per-formance of direct composite additions to correct tooth form and position. II. Marginal qualities. Clin Oral Invest 1997; 1: 19-26. 
